DEPARTMENT OF THE INTERIOR

UNITED STATES GEOLOGICAL SURVEY

PREPARED IN COOPERATION WITH

THE U.S. ATOMIC ENERGY COMMISSION

\title{
AEROMAGNETIC MAP OF THE BELTED PEAK QUADRANGLE AND PART OF WHITE BLOTCH SPRINGS QUADRANGLE NYE COUNTY, NEVADA \\ By
}

P. W. Philbin and B. L. White, Jr.

GEOPHYSICAL INVESTIGATIONS
MAP GP-514

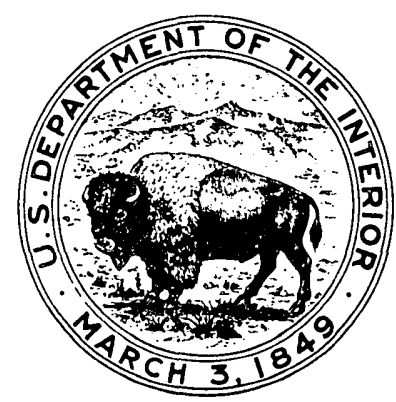

